\title{
INVESTIGATION OF THE INTERNAL STRUCTURE AND EVOLUTION OF THE HOLOCENE BARRIER OF MARICÁ (RIO DE JANEIRO, BRAZIL)
}

\author{
Carolina Pereira Silvestre ${ }^{1}$, André Luiz Carvalho da Silva², \\ Maria Augusta Martins da Silva ${ }^{3}$ and Amilsom Rangel Rodrigues ${ }^{4}$
}

\begin{abstract}
The objective of this study is the identification of the internal structure of the Holocene barrier of the Maricá coastal plain (Rio de Janeiro, Brazil) for the understanding of the evolution of this coast. The regional geomorphology is characterized by the large Maricá lagoon and by two sandy barriers which confines a series of small near-dry lagoons. Geophysical data obtained from ground-penetrating radar (GPR) images, with 400 and $200 \mathrm{MHz}$ shielded antennae and borehole samples, both reaching down to about 10 meters in depth, provided information about the sedimentary architecture and geological and oceanographical processes responsible for the evolution of this area in the Holocene. The results show that the barrier internal structure is formed by a set of strata presenting different geometries, dip directions and organization, relative to the following depositional environments: dunes, washover fans, beach and tidal channels. It was possible to determine the importance of the sea level changes, longshore currents and overwash processes for the barrier development. Strong reflectors representing eolian strata dipping towards the continent point out to a phase of barrier retrogradation; afterwards, a succession of very well preserved beach paleoscarps, located south of the previous barrier, shows a phase of barrier progradation. Such evidences indicate that the barrier evolved according to the Holocene sea level fluctuations recognized for the Brazilian coast.
\end{abstract}

Keywords: ground-penetrating radar, barrier-lagoon system, Holocene, Maricá coast.

RESUMO. 0 presente estudo objetivou identificar a estrutura interna da barreira holocênica buscando compreender a evolução da planície costeira de Maricá (Rio de Janeiro). A geomorfologia regional é caracterizada pela Lagoa de Maricá e duas barreiras arenosas, separadas por pequenas lagunas colmatadas. Dados geofísicos obtidos com um georadar, com antenas de 400 e 200 MHz, e amostras de sondagem geológica, ambos até a profundidade média de 10 metros, forneceram informações sobre a arquitetura sedimentar e os processos geológicos e oceanográficos responsáveis pela evolução desta área no Holoceno. Os resultados mostram que a estrutura interna da barreira é formada por um conjunto de estratos de diferentes geometrias, direções de mergulho e modos de organização relacionados aos seguintes ambientes deposicionais: dunas, leques de arrombamento, praias e canais de maré. Essas características permitiram o entendimento da dinâmica costeira responsável pelo desenvolvimento da barreira, com destaque para as variações do nível do mar, correntes de deriva litorânea e mecanismos de sobrelavagem. Refletores marcantes representando estratos eólicos inclinados para o continente indicam uma fase de retrogradação da barreira; a esse episódio se seguiu um período marcado por sucessivas paleoescarpas de tempestade, localizadas mais ao sul, indicando uma fase de progradação. Essas evidências mostram que a barreira evoluiu de acordo com as fases de transgressão e regressão marinha do Holoceno reconhecidas para o litoral brasileiro.

Palavras-chave: georadar, sistema barreira-laguna, Holoceno, litoral de Maricá.

\footnotetext{
1 Universidade Federal Fluminense, Oceans and Earth Dynamics, Department of Geology and Geophysics, Av. Gen. Milton Tavares de Souza s/n, Gragoatá, Campus da Praia Vermelha, 24210-346 Niterói, RJ, Brazil. Phone: +55(21) 2629-5930; Fax: +55(21) 2629-5931 - E-mail: carolinasilvestregeouff@hotmail.com

2Universidade do Estado do Rio de Janeiro, Department of Geography, R. Francisco Portela, 1470, Patronato, 24435-005 São Gonçalo, RJ, Brazil. Phone: +55(21) 3705-4631 - E-mail: andrelcsilvageouerj@gmail.com

3 Universidade Federal Fluminense, Department of Geology and Geophysics, Niterói, RJ, Brazil - E-mail: mariaaugustasilva0@gmail.com

${ }^{4}$ Universidade Federal Fluminense, Department of Geology and Geophysics, Oceans and Earth Dynamics, Niterói, RJ, Brazil - E-mail: amilsom2@uol.com.br
} 


\section{INTRODUCTION}

The evolution of Rio de Janeiro coastal plain (Fig. 1) was first studied by Lamego (1940, 1945), who, based on geomorphological characteristics, proposed that the barrier-lagoon systems have been formed by the closing of earlier embayments by spit growth. Such hypothesis was later endorsed by studies on the Jacarepaguá coastal plain, about $50 \mathrm{~km}$ from the present study area (Roncarati \& Neves, 1976). The evolution of the coast between Itacoatiara and Ponta Negra beaches (Fig. 1) was addressed by Perrin (1984) who established that the barrier-lagoon systems were formed in the Holocene by sea level fluctuations. Muehe (1984) presented evidences for the retrogradation of the Holocene barrier, as for example, the presence of a submarine outcrop of beachrock parallel to the Itaipuaçu beach. Ireland (1987) on the basis of diatom analysis collected from soundings from several lagoons from Itaipu to Guaratiba (Fig. 1), proposed that the inner barrier-lagoon system was formed in the Pleistocene and the outer barrier-lagoon system formed at about 7,200 years BP. Turcq et al. (1999) suggested that the inner barrier is $123,000 \pm 5,700$ years BP (based on lo/ $\mathrm{U}$ dating of corals from Bahia done by Martin et al., 1982), and that such barrier was drowned by the Holocene transgression which then originated the most recent barrier-lagoon system, between 7,000 and 5,000 years BP. Work carried on the Itaipuaçu coastal plain with GPR and boreholes identified a paleo barrier-lagoon; peat collected from the paleolagoon revealed the age of 6,040-5,900 years BP (Pereira, 2001; Pereira et al., 2003).

The results of a study integrating GPR, boreholes and AMS (Accelerator Mass Spectrometry) $14 \mathrm{C}$ data in this same area identified a $20 \mathrm{~m}$ thick late Quaternary sequence and proposed a model for the evolution of this Maricá area (Silva, 2011; Silva et al., 2014b). Three depositional sequences were recognized: the Pleistocene Sequence I, Pleistocene Sequence II (age between 48 and 45,000 cal years BP), and the Holocene Sequence (Fig. 2). The Holocene Sequence starts at about 8,560 cal years BP, the age of a beachrock that point out to the existence of a more southern barrier (about $100 \mathrm{~m}$ or so from today's mean sea level mark). This barrier system began then a phase of retrogradation as sea level rose through the Holocene up to 5,000 years ago. The internal structure observed on the Holocene part of this coastal plain with the $200 \mathrm{MHz}$ antenna, indicated this phase of retrogradation which, was then, followed by a phase 0 progradation, giving rise to the present-day barrier (Silva, 2011; Silva et al., 2014b). Today, the barrier is in a new phase of retrogradation due to a rise in the sea level (Silva, 2011; Silva et al., 2014b; Lins-de-Barros, 2005; Silva, 2006; Silva et al., 2008b).
This article aims to improve the knowledge about the Holocene barrier. That will be achieved by the use of a new GPR antenna (400 MHz) to provide a better visualization of the Holocene barrier architecture. Also, the work will contribute to the understanding of the mechanisms that controlled the barrier evolution during the time interval in question.

\section{Study area}

This work was developed at the Maricá APA, an environmental protection area in the central part of the Maricá coastal plain, in Rio de Janeiro State (Fig. 1). Although an environmental protected area, and thus relatively well preserved as compared to other coastal areas of Rio de Janeiro, illegal sand mining (among other activities) has been destroying the local endemic flora and fauna, as well as the landscape, and there is an increasing concentration of population in nearby areas mainly due to the construction of an oil refinery not far away. Despite this, the remaining landscape is suitable for GPR work.

The study area is characterized by the large Maricá Lagoon and by two barriers that confine a small plain containing a chainlike series of isolated swamps and nearby dry lagoons (Fig. 1). The area is about $9 \mathrm{~km}$ long and is limited by the Maricá Lagoon to the north and the Atlantic 0cean to the south (Figs. 1 and 3), to the west is the Itaipuaçu Beach and to the east the Guaratiba Beach (Figs. 1 and 3). The inner barrier is Pleistocene (Ireland, 1987; Turcq et al., 1999; Silva, 2011; Silva et al., 2014b) as the outer barrier is Holocene (Perrin, 1984; Maia et al., 1984; Ireland, 1987; Turcq et al., 1999; Pereira et al., 2003; Silva, 2011; Silva et al., 2014b).

The Holocene barrier is in average $7 \mathrm{~m}$ high, reaching maximum of $12 \mathrm{~m}$ em relation to mean sea level towards the central and east, and $5 \mathrm{~m}$ high towards the west of the area (Silva \& Silva, 2010). The barrier is about $220 \mathrm{~m}$ wide exhibiting a levelled out relief, consequence of sand mining; there is a well defined beach storm scarp limiting the beach and the maximum reach of storm waves (Silva \& Silva, 2010). Washover fans are present towards the east of the study area for about $2 \mathrm{~km}$ along the barrier (Fig. 3). On Itaipuaçu barrier, the formation of overwash fans are commonly observed during storms, depositing sands directly into the Canal da Costa (Fig. 1) (Silva et al., 2008b). Dunes occur mainly near the reverse face of the barrier (the barrier relief has been destroyed partially by the extraction of sand leaving a levelled surface) and are higher towards the east (Fig. 3) (Silva \& Silva, 2010). The beach at Maricá APA presents berms on the backshore and, sazonally, long channels parallel to the beach that turns perpendicular to it as the water escapes back to the sea; the foreshore is 

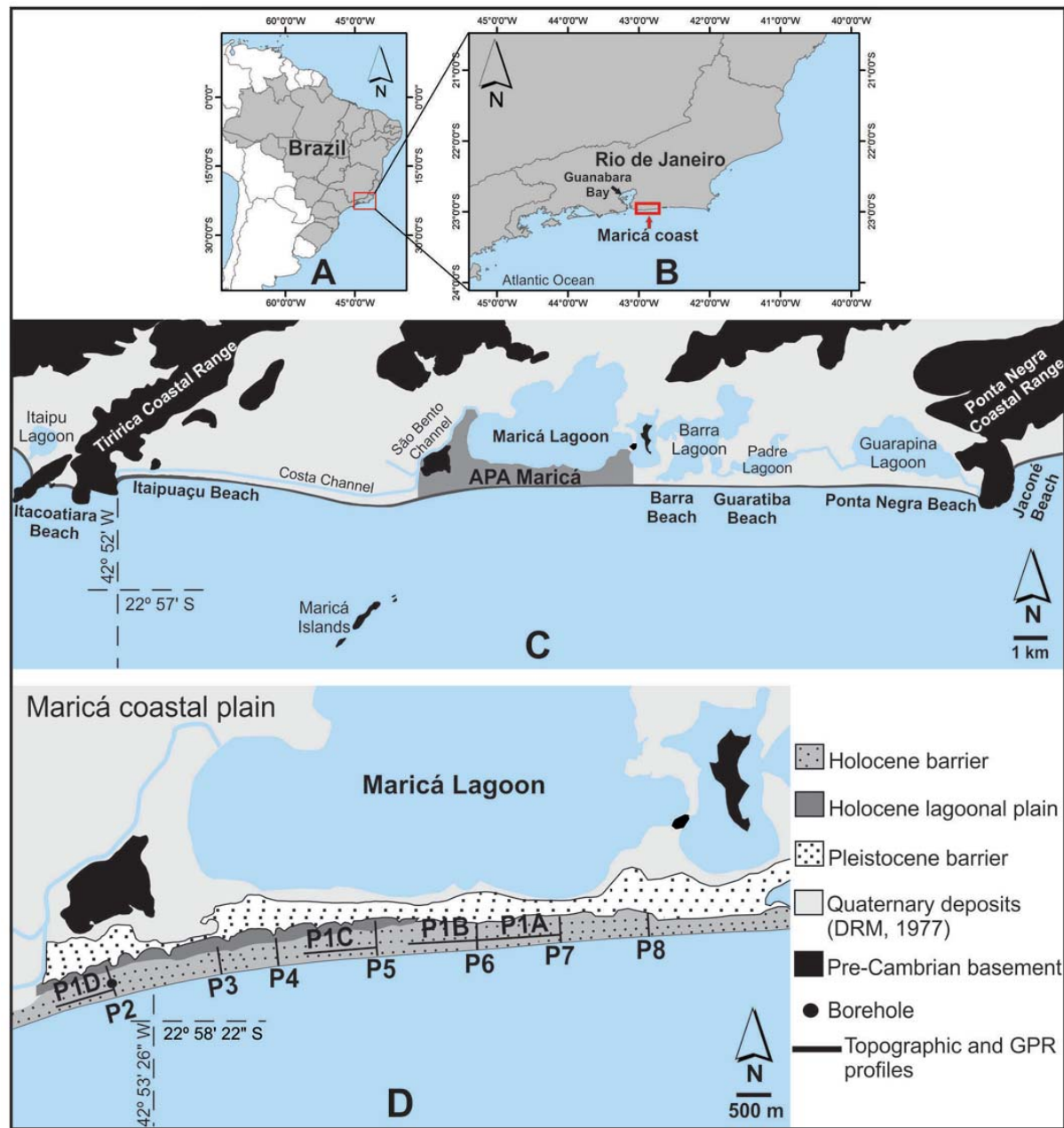

Figure 1 - (A and B) Location of the study area in Rio de Janeiro, southeast Brazil. (C) Study area (Maricá APA) in central coastal plain of Maricá. (D) Holocene barrier-lagoon system with topographic and GPR profiles and borehole locations. Geological Map (DRM-RJ, 1977).

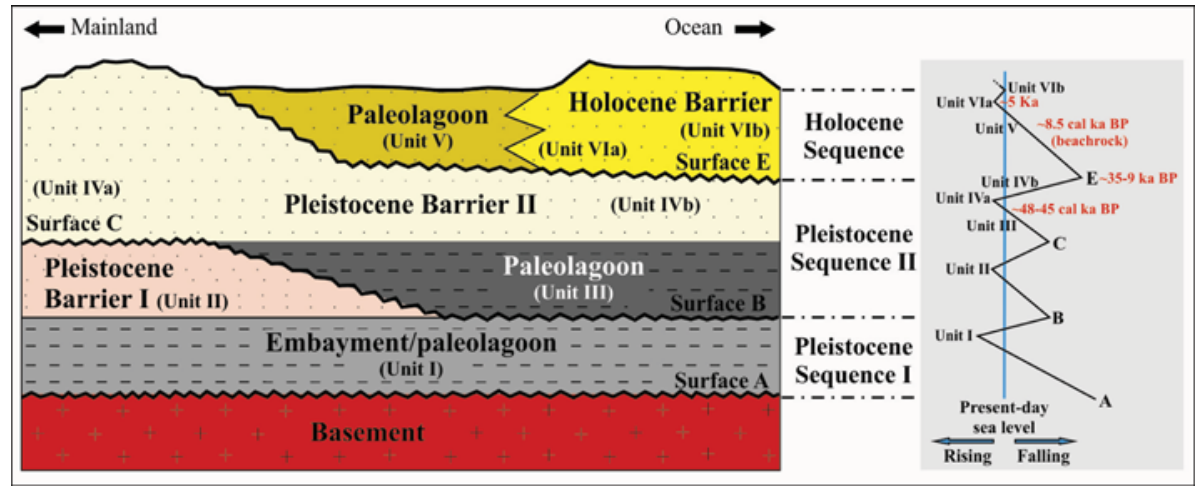

Figure 2 - Lithologic units and depositional sequences that form the coastal sedimentary deposit of Maricá (Silva et al., 2014b).

narrow and steep (Gralato, 2013). This is a wave-dominated coast with predominant S-SW storm waves during winter months, when waves can be $3 \mathrm{~m}$ high; SE waves prevail during fair weather con- ditions (Muehe, 1979; Silva, 2006; Silva et al., 2008a; Pardal, 2009). The predominant longshore currents are to the west in response to the SE waves. However, the occasional incidence of 


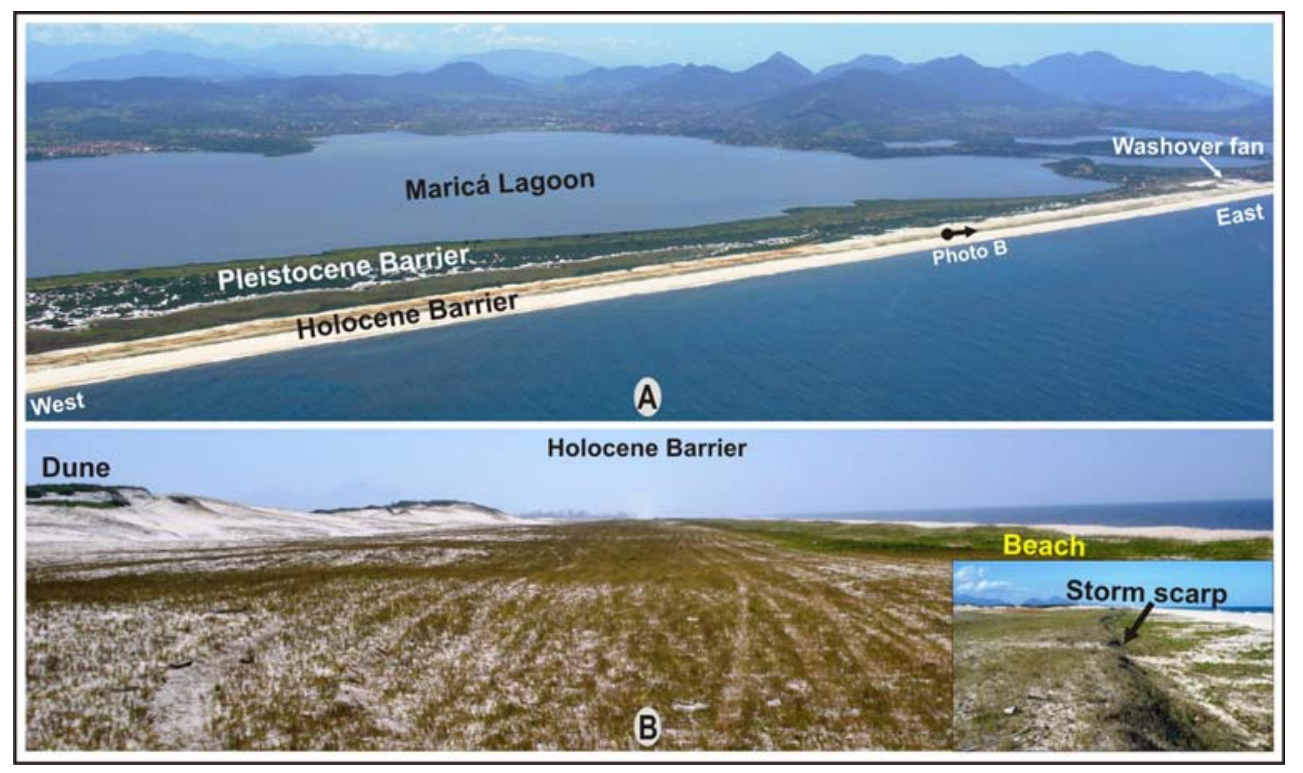

Figure 3 - (A) Aerial photo of the central coastal plain of Maricá: Maricá Lagoon to the North, two barriers (Pleistocene and Holocene) separated by the lagoonal plain. Photo by Guichard, D. 2009. (B) Geomorphology of the Holocene barrier (storm scarp in detail).

waves from more than one direction (SE and SW) contributes to the formation of longshore currents to the east as well (Silva et al., 2008a). Maximum spring tidal fluctuation is $1.5 \mathrm{~m}$ (Navy Hydrograph Directory - DHN). The wind climate is strongly influenced by the South Atlantic Subtropical anticyclone. The prevailing wind directions are from the east and northeast quadrants (Amarante et al., 2002). Occasionally, winds of stronger intensity come from the south and southwest associated with polar masses (CPTEC - INPE).

To attain the objectives of this work about the evolution of the Holocene barrier and its controlling mechanisms, GPR profiles and boreholes data were obtained (Fig. 1).

\section{MATERIALS AND METHODS}

The morphology of the Holocene barrier has been characterized by seven topographic profiles perpendicular to the coastline (from the beach to the landward face of the barrier) (Fig. 1). These profiles were obtained by conventional topographic equipment, always at times of calm sea and same tidal regime (quarter moon), and georeferenced with a Garmin GPS 12 XL equipment, the navigation system used was a WGS 84. A total of eight GPR profiles were obtained, seven perpendiculars and one parallel to the coastline (Fig. 1). The parallel profile is discontinuous due to obstacles and topographic depressions (illegal extraction of sand). A Georadar GSSI (Geophysical Survey Systems Incorporated) SIR-3000 model has been used (Fig. 4). 400 and $200 \mathrm{MHz}$ shielded antennae provided the best arrangement between res- olution and penetration depth of 10 to $15 \mathrm{~m}$, respectively. Data were processed in RADAN 6.6 (Radar Data Analysis) software, and included application of gains and filters, deconvolution, topographic correction and migration. Velocities have been determined from CMP (Common Mid-Point) surveys in nearby areas, as of $0.10 \mathrm{mns}^{-1}$ (Pereira, 2001). This is the medium velocity calculated from other CMP surveys in lagoonal muds and undersaturated and saturated sands below the water table (Neal \& Roberts, 2000 apud Neal, 2004).

The sandy sediments and the preservation of the environment are important factors for the high quality of the GPR data. The proximity to salty water is an impediment for high image resoIution as a function of signal attenuation, which, then turns impossible the observation of beach stratification. Trenches dug in these same sites in the 1970's were used to help recognize the beach inner structure. The parallel profile was obtained adapting the equipment to a vehicle (Fig. 4B), which was then driven along the sand, away $30 \mathrm{~m}$ from the road, avoiding the interference of the clay in the GPR data. Clays, like the salty water, affect the quality of the GPR images (Neal et al., 2002; Neal, 2004; Bristow \& Pucillo, 2006; Wang \& Horwitz, 2007; Silva, 2011).

OpendTect software was used for interpretation, which was based on the main reflectors and reflection patterns. Basic principles of seismic stratigraphy were applied to the radargram interpretation. Main patterns of reflections considered on this work are dip, shape, continuity, intensity and reflectors relationships (Neal, 2004). 


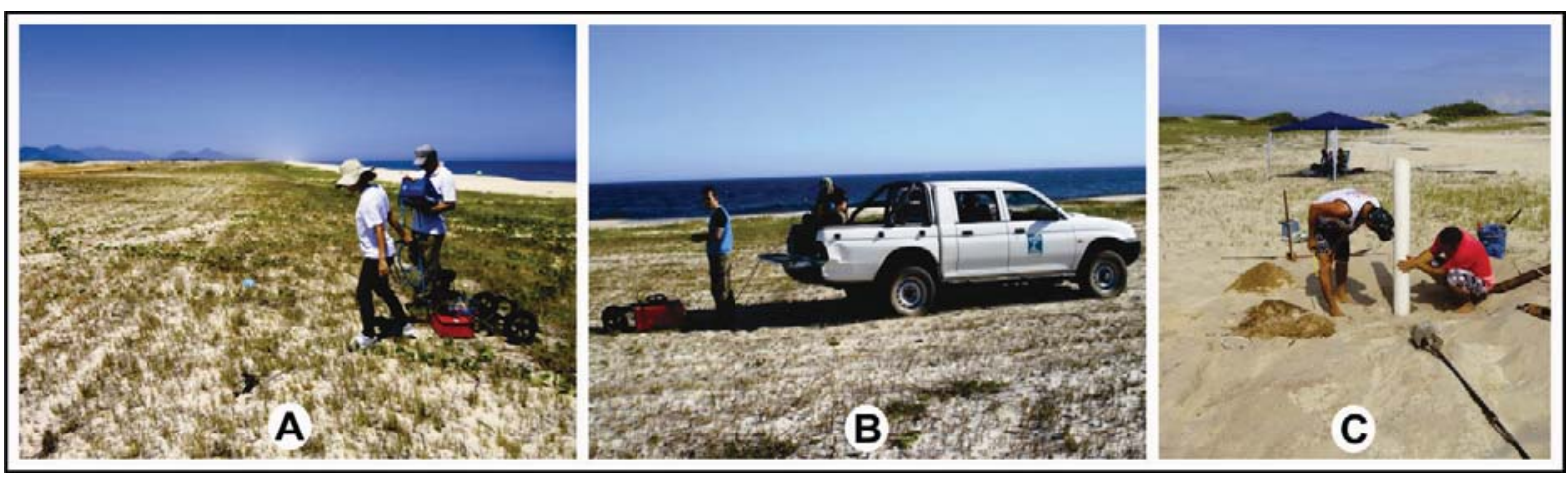

Figure 4 - Collecting GPR data: (A) $400 \mathrm{MHz}$ antenna carried by hand; (B) $200 \mathrm{MHz}$ antenna adapted to a vehicle; (C) Mechanical borehole.

One borehole was obtained by mechanical borer in the area of Profile 2, and about $60 \mathrm{~m}$ from the storm scarp (Fig. 4C). The decision about the location of this well was based on the analysis of GPR images in order to improve characterization of the observed layers, and assist in the interpretation of radargrams. The borehole reached the depth of $8.7 \mathrm{~m}$ and 20 samples were collected, at intervals of $0.5 \mathrm{~m}$ or when the sedimentary characteristics changed. These samples were described while in the field, and later grain size analyses were carried out and sediment classified according to Wentworth (1922 apud Pettijohn, 1975).

\section{DATA PRESENTATION}

\section{Ground Penetrating Radar Profiles}

The radargrams showed high resolution, intense and continuous strata and reflexions patterns down to depths of about $10 \mathrm{~m}$ for the $400 \mathrm{MHz}$ antenna and $15 \mathrm{~m}$ for the $200 \mathrm{MHz}$ antenna. The perpendicular profiles with the $400 \mathrm{MHz}$ antenna presented excellent image between the landward face of the barrier and the beach storm scarp. On the beach, the image looses resolution due to signal attenuation as a function of the salty water (Neal et al., 2002; Daly et al., 2002; Neal, 2004; Silva, 2011, among others). These problems are sometimes impossible to correct during processing and they should not be considered for interpretation (Neal, 2004). The parallel profile along the barrier presented good resolution, in special the ones with the $400 \mathrm{MHz}$ antenna. The perpendicular profiles exhibit geometries and reflexion patterns which allowed the mapping of depositional unities, and prominent reflectors which are unit limits (Fig. 5). The Holocene barrier internal structure presents stratification arrangements which indicate phases of retrogradation and progradation. The parallel profiles (Figs. 6 and 7) show sets of reflectors that represent strata filling paleochannels; other reflectors seen in these parallel profiles represent major strata inclined both to east and west, which suggests barrier lateral migration, as in a spit growth.

A continuous, horizontal and strong reflector appears in all profiles (Figs. 5 and 7), in depths varying from few centimeters (along the lagoonal plain) to about $5 \mathrm{~m}$ (underneath the area of dunes). It corresponds to the water table, as previously mapped by Silva (2011) and also confirmed by drilling during this work.

Along Profile 2, between the dunes area and the levelled surface of the barrier, at about $7 \mathrm{~m}$ deep, occurs a $75 \mathrm{~m}$ long reflector, horizontal to slightly inclined towards the sea, here named Reflector $\mathrm{F}$ (Fig. 5A). This Reflector $\mathrm{F}$ is the upper limit of an area of low reflectance which indicates the presence of mud at this depth, confirmed by borehole (Fig. 8).

At depths varying from 7.5 to $3.5 \mathrm{~m}$, below the dunes area, is possible to visualize (1) a set of layers dipping 5 to $45^{\circ}$ landwards (Fig. 5, black arrow); (2) towards the south, strata near horizontal to slightly inclined to the sea (Fig. 5). This depth interval is composed by sand (Fig. 8), probably deposited by wind, and it is limited by Reflectors F (Profile 2) and G (Profiles 2, 6 and 8) (Fig. 5). Reflector $\mathrm{G}$ is inclined towards the sea and may represent a former barrier surface formed by erosion due to overwash processes. The geographic position of this deposit suggests a phase of retrogradation of the barrier, reaching its northernmost position during the Holocene. On top of this deposit, at depths between 3.5 and $2.0 \mathrm{~m}$, a lenticular shaped layer of sand is present, limited by Reflectors $G$ and $H$ (Fig. 5). This layer shows many internal reflectors dipping 10 to $20^{\circ}$ landwards, on the landward faces of the barrier, and more horizontal reflectors towards the south (Fig. 5), a pattern which suggests overwash processes and formation of overwash fan (Fig. 5). The sedimentary layer between the Reflectors $F$ (Profile 2) $\mathrm{G}$ and $\mathrm{H}$ appears to have been truncated further south of the barrier (Fig. 5).

From $7 \mathrm{~m}$ deep to near the surface, under the levelled surface of the barrier to the present-day beach storm scarp (Fig. 5), 

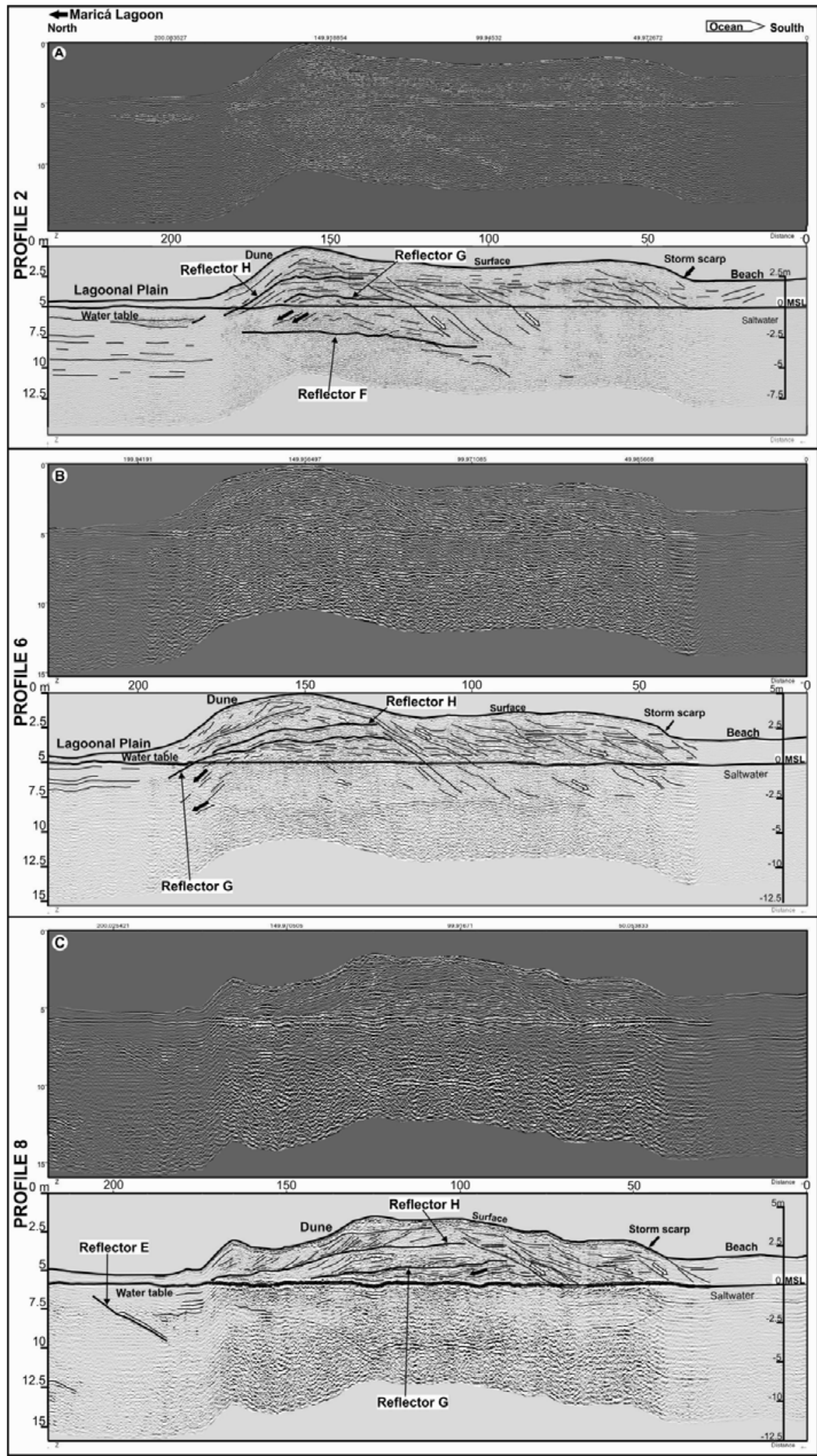

Figure 5 - (A, B and C) GPR Profiles 2, 6 and 8, perpendicular to the coastline, with $400 \mathrm{MHz}$ antenna. 


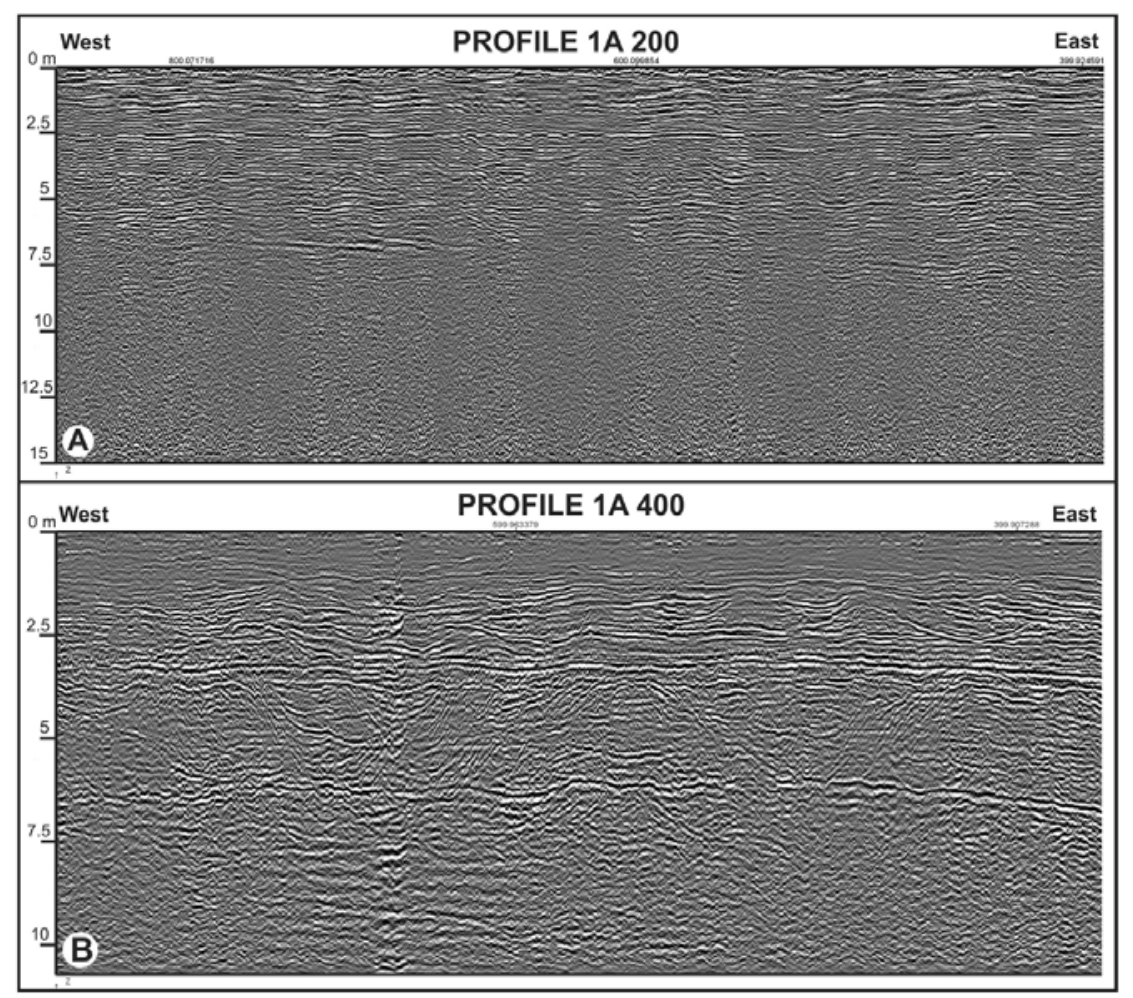

Figure 6 - Profile 1A: Comparison between resolutions 200 and $400 \mathrm{MHz}$ antennae.

we observe a set of reflectors dipping 22 to $40^{\circ}$ seawards that truncates near horizontal beds (Fig. 5 - white arrow). Such arrangement is very similar to the one observed along modern beach storm scarps as it can be visualized in a trench dug in a nearby area in the 1970's (Fig. 9). In the trench, surfaces dipping to the sea representing the removal of sand from the beach by storm waves leaving an inclined surface and a beach scarp clearly truncate near horizontal beds representing earlier berms; a new set of horizontal or near horizontal layers are seen on top of the truncation surface as the beach recovers its sand and gets wider. The implication, is that, the beach was located farther inland indicating that the barrier progressively prograded to a new position.

Between Reflector $\mathrm{H}$ and the surface, a $2.5 \mathrm{~m}$ thick sand deposit shows plane-parallel strata inclined $30-35^{\circ}$ landwards as well as cross beds typical of dunes (Fig. 5). There is a distinct reflector inclined to the continent, in the middle of this sand deposit, that may represent the migration surface of the dune (Profiles 6 and 8 - Fig. 5).

From the present-day storm scarp, which represents the beach limit, on towards the beach, it is difficult to visualize any reflectors due to the influence of the salty water. Few are recognizable, though, and they are plane-parallel layers dipping landwards which may represent berms (Fig. 5). The internal beach structure seen in the trench in nearby Itaipuaçu (Fig. 9) help the identification of the characteristic stratification of this environment: near horizontal layers truncated by surfaces inclined 10 to $16^{\circ}$ to the sea. The inclined surfaces represent removal of sand by storm waves which leaves a steep and shortened beach, that latter recovers its width by the accreting sands forming new berms, typical of beach dynamics.

The parallel Profile 1 (Figs. 7A and B) was obtained along the length of the Holocene barrier (Fig. 1) with the 200 and $400 \mathrm{MHz}$ antennae. The profile covered, discontinuously, the area from west to east due to obstacles for the dislocation of the equipment. The $400 \mathrm{MHz}$ antenna better displayed the barrier internal structure (Fig. 6). In this work, only two of the sections collected with the $400 \mathrm{MHz}$ antenna are presented (Fig. 7).

The Pleistocene/Holocene boundary is observed on Profile 1 (Reflector E - Fig. 7), as an erosive surface as previously defined by Silva (2011). This erosive surface was also observed on Profile 8 (Fig. 5C). Reflector $\mathrm{E}$ appears, at about $8 \mathrm{~m}$ of depth, as a discrete (and more proeminent to the west), near horizontal and discontinuous, extending for about $340 \mathrm{~m}$ (Profile 1D - Fig. 7B). Above Reflector $\mathrm{E}$, between 8 and $3 \mathrm{~m}$ of depth, a sandy deposit exhibits a variety of stratification patterns (Fig. 7): 


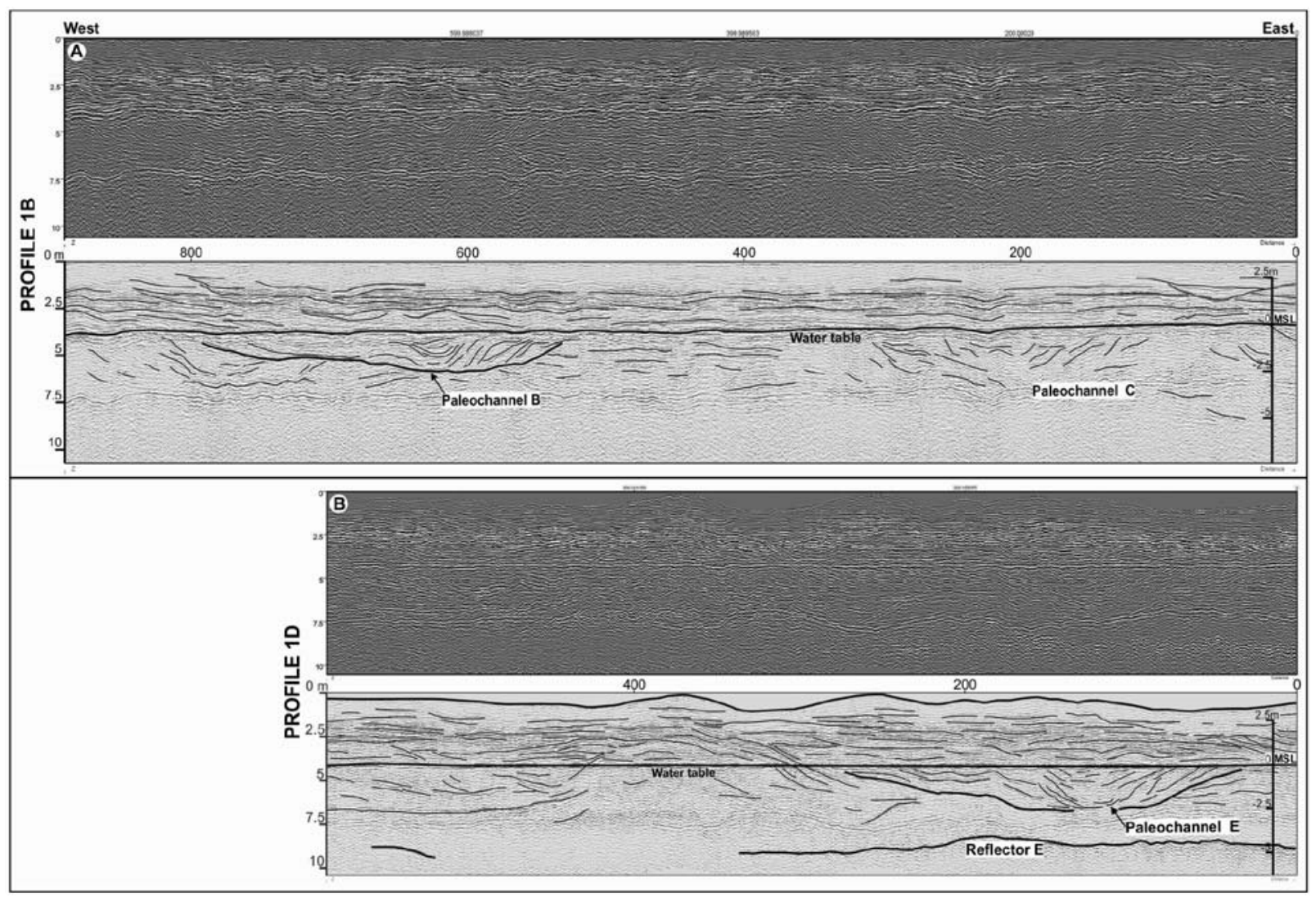

Figure 7 - Section of the GPR Profile 1 acquired parallel to the shoreline with $400 \mathrm{MHz}$ antenna. (A) Profile 1B and (B) Profile 1D.

(1) layers dipping 6 to $45^{\circ}$ to the east;

(2) plane-parallel near horizontal strata;

(3) strata dipping 11 to $45^{\circ}$ to the west; and

(4) a cut-and-fill pattern indicative of paleochannels.

Three paleochannels were identified at depths between 6 and $3 \mathrm{~m}$ along the barrier (Profile 1 - Fig. 7), varying from 240 to $260 \mathrm{~m}$ of width and about $3 \mathrm{~m}$ of depth. These channels' sedimentary infillings are characterized by layers dipping both to east and west, and the concave shape of some surfaces is indicative of the progressive shallowing of these paleochannels (Fig. 7).

From the depth of $3 \mathrm{~m}$ to the barrier surface, near horizontal layers predominate, showing concave up and convex geometries, while some others are slightly inclined both to east and west (Profile 1 - Fig. 7). In the uppermost $1 \mathrm{~m}$ section of this profile no reflectors are observed (Fig. 7).

\section{Borehole}

The borehole (Fig. 8, see Fig. 1 for location) presented only two lithologies: a basal mud layer, between the depth of 8.5 and $7.5 \mathrm{~m}$; and $7 \mathrm{~m}$ thick layer of sand on top (Fig. 8). Grain size analyses of 20 samples indicated that coarse sand predominates (Fig. 8).

The basal mud layer is black with an intense smell of organic matter decomposition, presents whole shells as well as fragments, and plane-parallel layering (Fig. 5). This mud layer changes upwards (around 7.2 to $7 \mathrm{~m}$ depth) to a thin layer of a coarse dark brown sand, possible muddy (Fig. 8). These are characteristics of sediments deposited in a lagoonal environment. In nearby Itaipuaçu beach (Fig. 1), at the same geological setting and depth, a paleolagoon was identified and sediments were $\mathrm{C}^{14}$ dated providing the age of 6,040-5,900 years BP (Pereira, 2001; Pereira et al., 2003).

The upper sand layer (Fig. 8), from $7 \mathrm{~m}$ deep to the surface, is coarse and quartz rich with feldspars and few shells. Between 5.5 and $6.5 \mathrm{~m}$ depths the sand is light gray or white (Fig. 8). This type of sand is characteristic of the Pleistocene barrier (Silva, 2011; Silva et al., 2014b). The rest of the sand section, from $5 \mathrm{~m}$ up to the surface, is composed by a coarse light yellow or brownish sand (Fig. 8). The water table is reached at an average depth of $4 \mathrm{~m}$. 


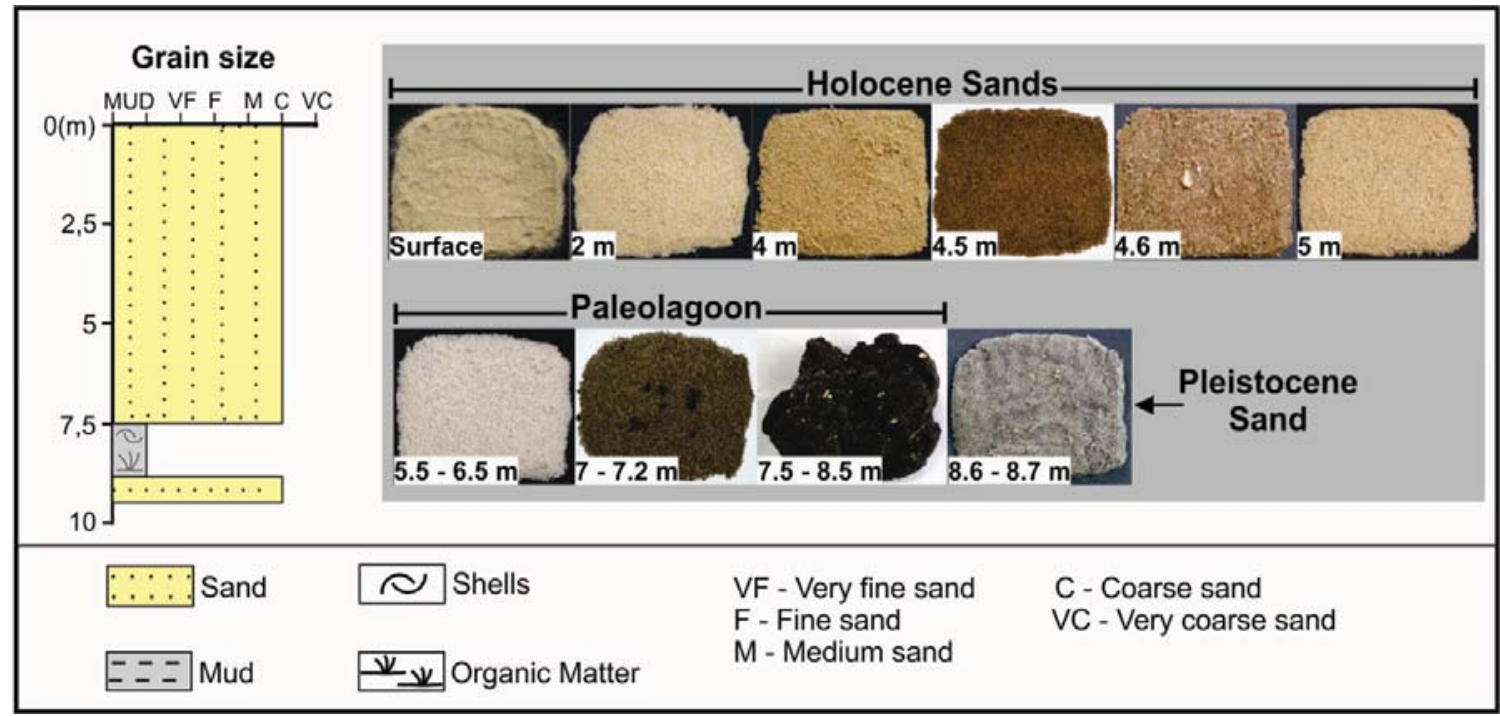

Figure 8 - Main characteristics of the sediments collected with the borehole.

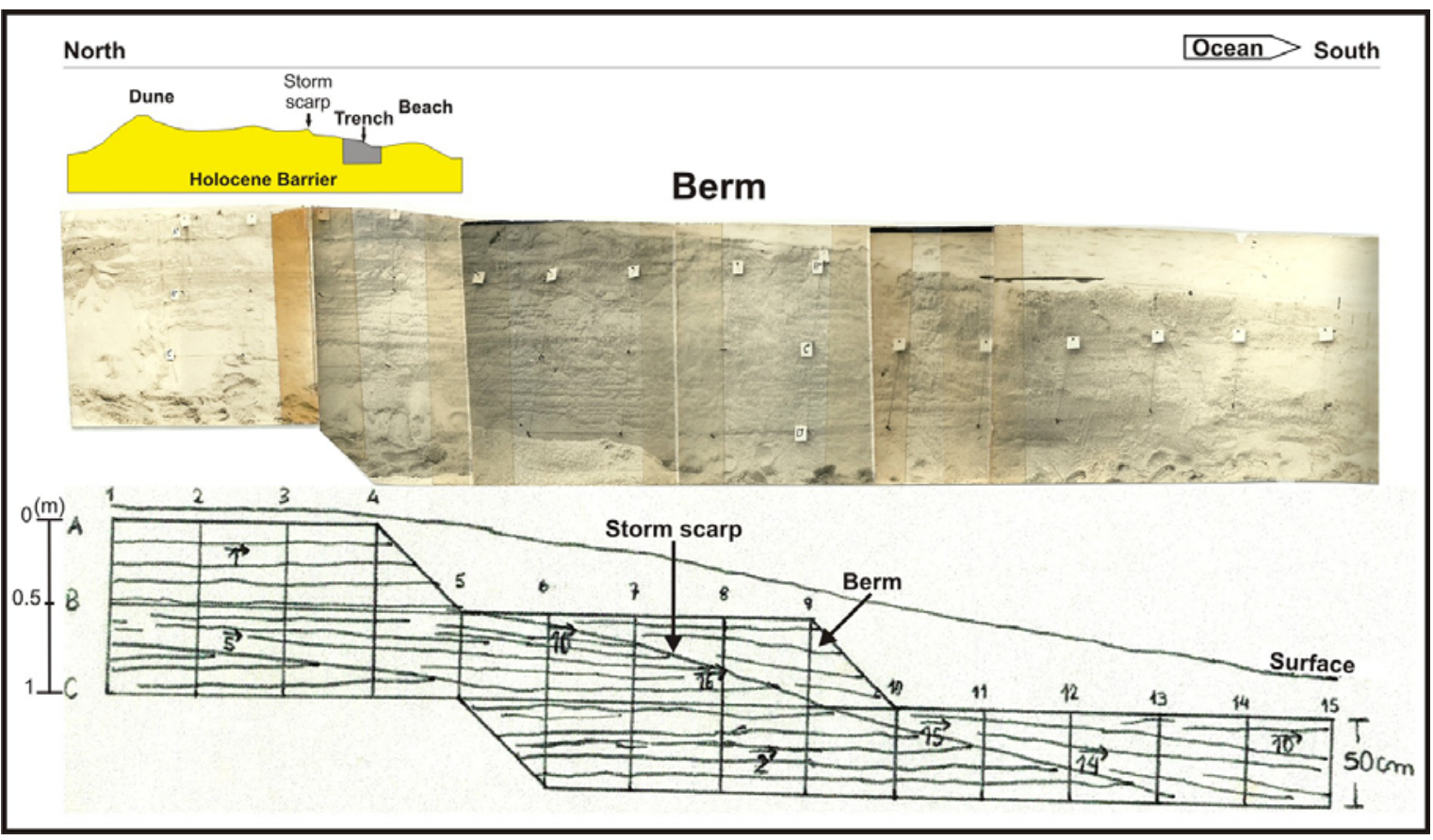

Figure 9 - Trench in nearby Itaipuaçu Beach (see Fig. 1 for location) showing the beach internal structure (report to CNPq by Silva, 1972).

\section{DISCUSSION}

The main reflectors and reflexions patterns mapped, and the samples collected in the boreholes allow the identification of two lithological unities: (1) a basal mud layer which is here interpreted as been deposited in a paleolagoon; (2) an overlying $7 \mathrm{~m}$ thick sand layer which represents the Holocene barrier (Fig. 10). The depositional architecture of the barrier-lagoon sys- tem was revealed through a set of stratification presenting different geometries, dip angles and directions and organization, pointing out to the presence of earlier dunes, overwash fans, beach and beach storm scarps (Fig. 10). Major reflectors organized with dips either towards land and to the sea indicate phases of retrogradation and progradation of the barrier through the Holocene (Fig. 10). 


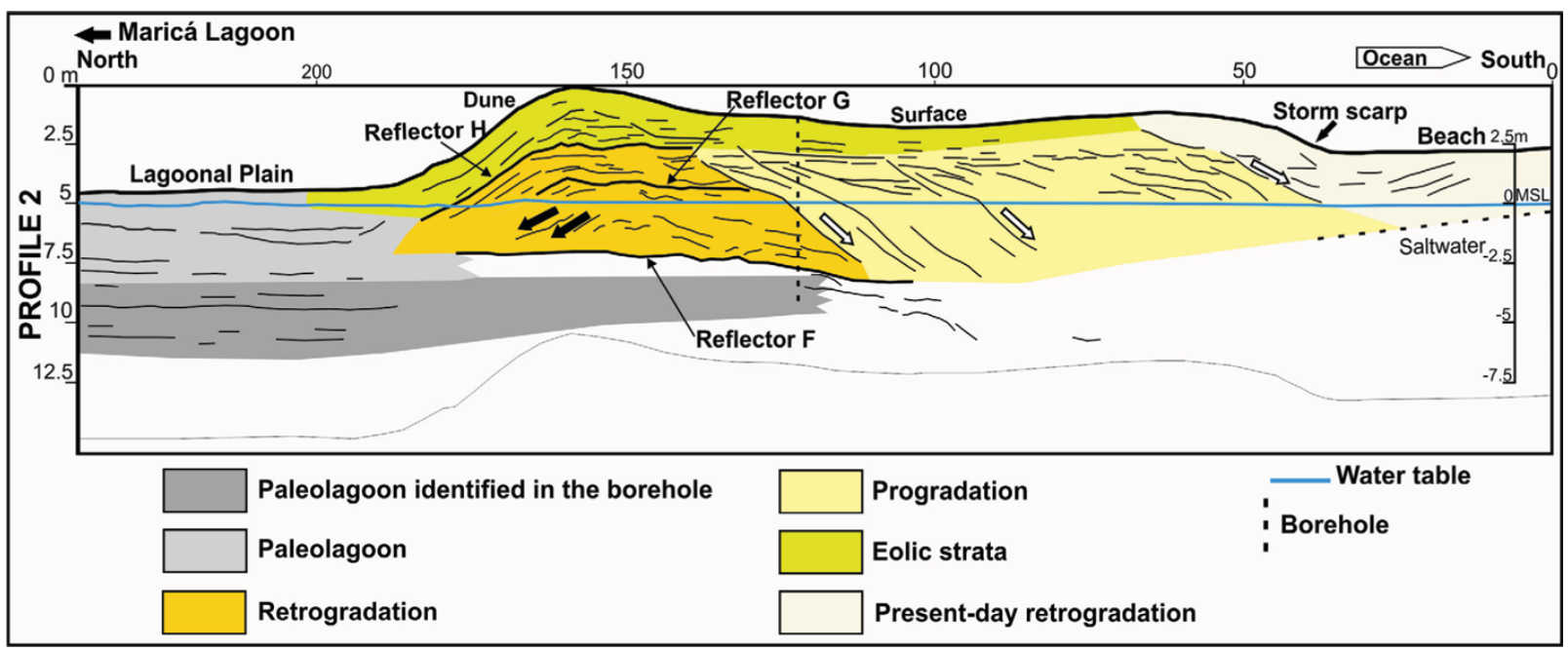

Figure 10 - Depositional architecture of the Holocene barrier-lagoon system (based mainly on Profile 2)

Surface $\mathrm{E}$ (Figs. $5 \mathrm{C}$ and 7), the boundary between the Pleistocene and Holocene, is present throughout the area, from the lagoonal plain to the Holocene barrier, as proposed by Silva (2011) and Silva et al. (2014b) and confirmed by the present work. Surface E continuation across the Holocene barrier is difficult to observe due to the nearness to the salty water. This surface E was formed by an erosive process during land exposure in a low sea level phase (Silva, 2011; Silva et al., 2014b).

The lower section of the sequence is here represented by a mud layer that changes upwards to a sandy mud layer; the basal mud shows plane-parallel bedding, mostly under the lagoonal plain (Figs. 5 and 10). This sedimentary unit is similar to the one found in Itaipuaçu and, there, it was dated as 6,000 years BP (Pereira, 2001; Pereira et al., 2003). The extension of this mud layer under the Holocene barrier is an evidence for a retrograding phase of an earlier barrier located farther south (Silva, 2011; Silva et al., 2014). Such barrier can be identified as the 8,560 years cal BP beachrock outcrop present along the Itaipuaçu nearshore (Silva, 2011; Silva et al., 2014a; Silva et al., 2014b). The beachrock and the lagoonal mud layer form the base of the Holocene Coastal Sequence as defined by Silva (2011) and Silva et al. (2014b).

At about $150 \mathrm{~m}$ from mean tide level and from 7.5 to $3 \mathrm{~m}$ of depth, sands exhibiting stratification dipping 20-45 landwards mark the innermost reach of the barrier during the Holocene. This deposit, here interpreted as dunes, is over the lagoonal muds (arrows Fig. 10). This is best observed along Profile 2 and disappears towards the east where the Holocene sands directly overlie on the Pleistocene sand. The position of the bar- rier here is probably related to the maximum sea transgression during the Holocene at 5,100 years BP (Ireland, 1987; Turcq et al., 1999; Pereira et al., 2003; Silva, 2011; Silva et al., 2014a). This retrograding phase of the barrier has been already indicated by Silva (2011) and Silva et al. (2014b) for this Maricá coastal area, and also in Itaipuaçu coast (Pereira, 2001; Pereira et al., 2009).

The barrier was then partially eroded by storm waves which gave rise to an erosive surface (represented by Reflector $G$ Fig. 10). To the south, this erosive surface seems truncated by another surface (Figs. 5 and 10) and the relationship between them is similar to present-day beach storm scarps (Fig. 9). Over the erosive surface $\mathrm{G}$, and limited by Reflector $\mathrm{H}$, from 2.7 to $1.7 \mathrm{~m}$ depth, occurs a sand deposit presenting layers which are planeparallel horizontal as well as inclined $10-20^{\circ}$ landwards, similar to the architecture of washover fans (Figs. 5 and 10) (McCubbin, 1982). Washover fans are seen today along this barrier on the study area (Fig. 3) and along the Itaipuaçu barrier (Silva et al., 2008b). In subsurface, examples were presented with GPR images also in Itaipuaçu (Pereira, 2009). Storm waves and washover fan formation compose an important process forcing the retrogradation of a barrier in different parts of the world (Morton, 2002; Morton \& Sallenger, 2003; Dillenburg et al., 2004; Donnelly et al., 2004; Caldas et al., 2006; Switzer et al., 2006; Wang \& Horwitz, 2007; Houser et al., 2008; Matias et al., 2008; Sedrati et al., 2011; Phantuwongraj et al., 2013).

During most of the last 5,100 years $\mathrm{BP}$, the barrier prograded (Fig. 10) as sea level lowered along the Brazilian coast (Martin et al., 1987 apud Martin et al., 2003; Angulo \& Lessa, 1997). The 
prograding barrier is composed by coarse sand characterized by a succession of plane-parallel horizontal to near horizontal stratification truncated by surfaces with dips varying from $20^{\circ}$ to $40^{\circ}$ to the sea, resembling today's beach storm scarps (Figs. 9 and 10). The horizontal to near horizontal strata represent berms, and the whole unit clearly shows past location of the beach positions and its progradation through time. The main source of sand was the shoreface and the continental shelf since there are no rivers supplying sediments to this coastal area.

The phase of retrogradation, which was then followed by progradation, has been also observed in different barrier systems of the Brazilian coast and considered the result of sea level fluctuations during the Holocene (Tomazelli et al., 2000; Tomazelli \& Dillenburg, 2007; Guedes et al., 2011).

The three paleochannels mapped along the barrier at depths varying from 6 to $3 \mathrm{~m}$ (Fig. 7) seem to be associated with the progradation phase of the barrier. The sediments in these channels show strata dipping either to west and east (slightly predominating). In Itaipuaçu, similar paleochannels were also found in the Holocene barrier though deeper (depth of 10 to $15 \mathrm{~m}$ ) (Pereira, 2001; Pereira et al., 2003).

On the area of dunes, from the surface to depths of 1.5 to $3 \mathrm{~m}$, a coarse quartz sand deposit with planar cross-strata showing dips of 30-45 landwards is found (Figs. 5 and 10). Such coarse sands dunes is not usual, but in the Maricá coast coarse sand dunes have been observed today to under storm wind conditions (Silva et al., 2014c). It is here proposed, though preliminary, that these earlier dunes are associated to the phase of barrier progradation.

On the beach, despite the low quality of the radargrams, plane-horizontal stratification such as observed on berms (Fig. 9) was identified (Fig. 10).

Large-scale stratification found in depths varying from 7 to $3 \mathrm{~m}$ on Profile 1 (Fig. 7) shows dips either to west and east (in this case, slight predominant), and could be an indication of longshore currents playing a role on the barrier formation as a spit. The data are not conclusive and needs further research, but it may be an evidence that, at times, the evolution of the barrier was the result of sea level fluctuation as well as the drifting of sands by longshore current, a combination of causes, hypothesis proposed by Schwartz (1971) for the evolution of barrier systems.

Holocene sea level curves for the Brazilian coast (Martin et al., 1987 apud Martin et al., 2003; Angulo \& Lessa, 1997) show that sea level overtopped today's level at about 7,000 years ago and reached a maximum of 3 to $5 \mathrm{~m}$ above present-day level at about 5,100 years ago. After that, sea level gradually fell to its present position. The geomorphology and architecture of the barrier are in agreement with the sea behavior during the Holocene pointing out a phase of retrogradation followed by progradation. Based on existing historical photos and comparison to today's geographic position of the barrier crest, the work carried on along the Maricá coast indicates that the barrier is in a new phase of retrogradation, in the order of 15 to $30 \mathrm{~m}$ for last 30 years (Lins-de-Barros, 2005; Silva, 2006; Silva et al., 2008b).

In summary, five phases could be identified related to a model for the barrier evolution during the Holocene, starting with (Fig. 11): (1) a barrier located towards the south which gave rise to a beachrock formation at about 8,560 years cal BP (Fig. 11A), as proposed by Silva et al. (2014a; 2014b). (2) A lagoon was associated to this barrier since a mud layer is found under the barrier as the sea progressively rose (the Holocene transgression) and promoted retrogradation of the barrier (Fig. 11B). (3) The transgression reached a maximum at about 5,100 years BP (Figs. 11B and $\mathrm{C}$ ). During this time interval, the barrier was partially eroded by overwash process which left an erosive surface and washover fans as records of this phase (Fig. 11C); (4) a sea level fall and progradation of the barrier, seen as a succession of beach storm scarps (Fig. 11D); and (5) for the last 30 years, sea level has been rising leading to the retrogradation of the barrier (Lins-de-Barros, 2005; Silva et al., 2008b).

\section{CONCLUSIONS}

With this work it was possible to improve the understanding of the formation and the evolution of the Maricá Holocene barrier (Rio de Janeiro). GPR data combined to sample collected from boreholes allowed the visualization of the barrier inner structure and architecture down to about $10 \mathrm{~m}$ deep and its sedimentary characteristics.

The results indicated the presence of a basal mud layer, about $1 \mathrm{~m}$ thick, deposited in a lagoon; on the top of it, a $7 \mathrm{~m}$ thick coarse sand layer represents the Holocene barrier. The barrier exhibits distinct reflexion patterns which permits to individualize phases of barrier migration during the Holocene: (1) At approximately 8,000 years BP, beachrock in nearby areas (Itaipuaçu and the Jaconé beaches) are evidences for a barrier located towards the south (today's nearshore zone) and the onset of sedimentation in the area in the Holocene (Silva, 2011; Silva et al., 2014a; Silva et al., 2014b); (2) on the reverse face of this barrier, a lagoon was present; sediments collected from a similar lagoonal mud layer in Itaipuaçu indicated the age of about 6,000 years BP (Pereira, 2001; Pereira et al., 2003). The stratigraphic position 


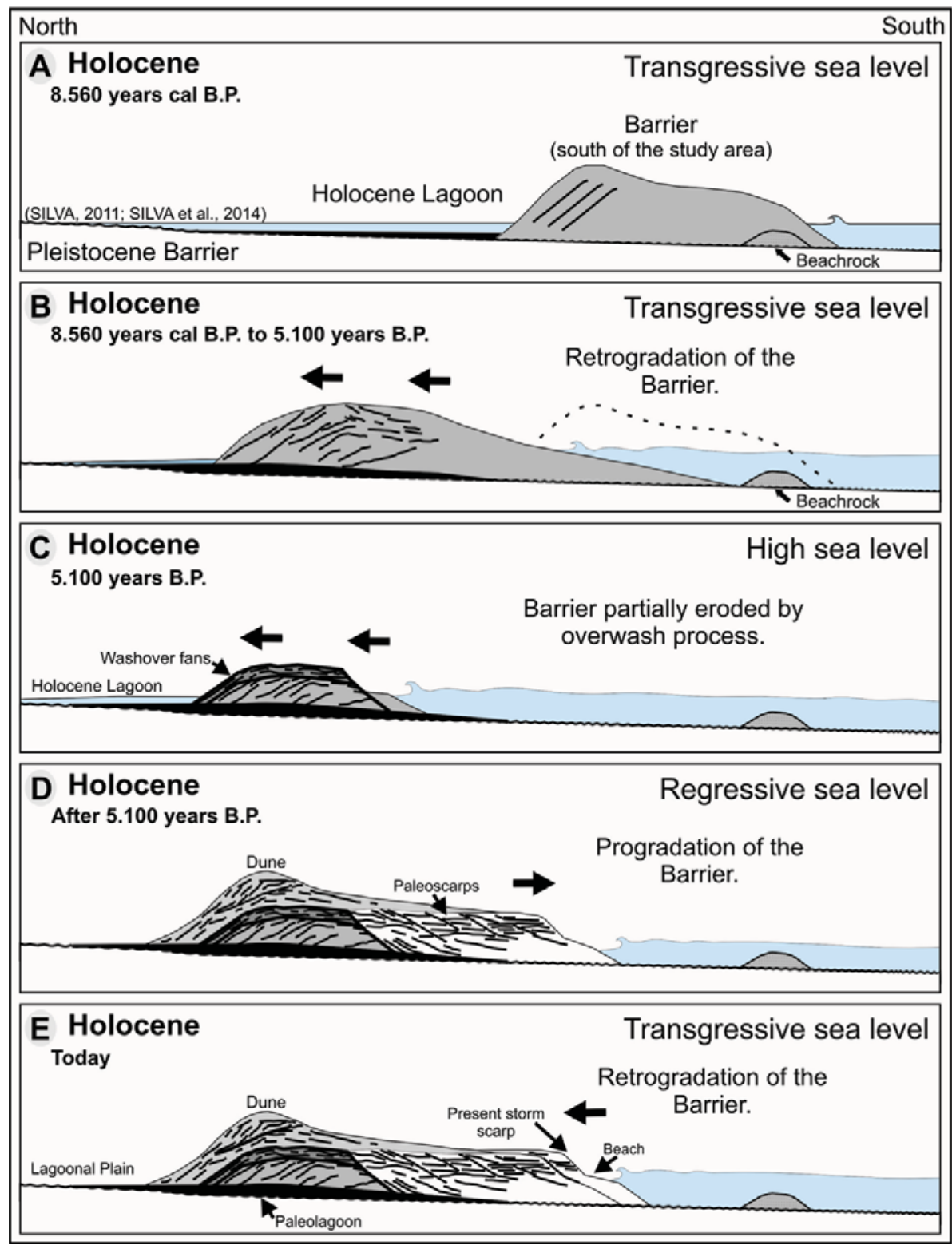

Figure 11 - Proposed model for the evolution of the barrier-lagoon system of Maricá (RJ).

of the mud layer points out a transgressive sea (the Holocene Transgression). The surface of this mud layer is marked by Reflector F; (3) the barrier begun to retrograde to a more northern position in response to a gradual sea level rise, which reached its maximum at about 5,100 years BP. The barrier sands overtopped the lagoonal mud or were deposited over the erosive surface F; (4) intensive storm waves partially eroded the barrier leaving a surface representing such events (Reflector $G$ ) and formed washover fan deposits (limited by Reflector $\mathrm{H}$ ); (5) the subsequent falling of the sea level, during the last 5,100 years, caused the progradation of the barrier. This phase of progradation is characterized and can be recognized by a succession of beach storm scarps; also, in this prograding barrier system, paleochannels seemed to be present. The sediments filling these channels show layers dipping either to west and east (this last direction slightly predominates); (6) A set of eolian cross-strata, forming a $2 \mathrm{~m}$ thick deposit, located at the barrier crest, is probably related to this phase of progradation; and (7) For the last 30 years, the Maricá barrier system shows a retrograding behavior (Lins-deBarros, 2005; Silva et al., 2008b). 
The Maricá barrier-lagoon system seems to have evolved mostly as a result of sea level fluctuation during the Holocene (no other main factor, such as sediment supply from rivers, can be considered here for lack of evidences). Longshore currents may also have played, at times, an important role in the formation and evolution of the barrier as a spit, and most of all, intense storm waves were significant concerning the coastal dynamic processes shaping the barrier.

\section{ACKNOWLEDGEMENTS}

Special thanks to CAPES for the master degree scholarship. During field work, Sérgio Cadena help the authors with GPR acquisition; also Drs. Alberto Figueiredo Jr. and Guilherme Fernandes, both from UFF, for lending the vehicle and equipment that made this work possible. To Ronaldo and his team for their professional attitude during the drilling phase of the research. Thank all the students and colleagues who cooperated in many different ways to this work.

\section{REFERENCES}

AMARANTE OAC, SILVA FJL \& RIOS FILHO LG. 2002. Estado do Rio de Janeiro: Atlas Eólico. Secretaria de Estado de Energia, da Indústria Naval e do Petróleo, Camargo Schubert, 83 pp.

ANGULO RJ \& LESSA GC. 1997. The Brazilian sea-level curves: a critical review with emphasis on the curves from Paranaguá and Cananéia regions. Marine Geology, 140: 141-166.

BRISTOW CS \& PUCILLO K. 2006. Quantifying rates of coastal progradation from sediment volume using GPR and OSL: the Holocene fill of Guichen Bay, south-east South Australia. Sedimentology, 53: 769-788.

CALDAS LHO, STATTEGGER K \& VITAL H. 2006. Holocene sea-level history: Evidence from coastal sediments of the northern Rio Grande do Norte coast, NE Brazil. Marine Geology, 228: 39-53.

CPTEC-INPE. Centro de Previsão de Tempo e Estudos Climáticos Instituto Nacional de Pesquisas Espaciais. Available on:

<http://ondas.cptec.inpe.br/>. Access on: October 30, 2012.

DALY J, McGEARY S \& KEANTZ DE. 2002. Ground-penetrating radar investigation of a late Holocene spit complex: Cape Henlopen, Delaware. Journal of Coastal Research, 18(2): 274-286.

DILLENBURG SR, TOMAZELLI LJ \& BARBOZA EG. 2004. Barrier evolution and placer formation at Bujuru southern Brazil. Marine Geology, 203: 43-56.

DONNELLY JP, BUTLER J, ROLL S, WENGREN M \& WEBB III T. 2004. A Backbarrier Overwash Record of Intense Storms from Brigantine, New Jersey. Marine Geology, 210: 107-121.
DRM-RJ. 1977. Departamento de Recursos Minerais do Estado do Rio de Janeiro. Mapa Geológico do Estado do Rio de Janeiro, Brazil. Escala 1:400.000.

GRALATO JCA. 2013. Variabilidade sazonal da praia na APA de MaricáRJ. Monograph, Dept. de Geografia, Faculdade de Formação de Professores - UERJ, São Gonçalo, Rio de Janeiro, Brazil. 115 pp.

GUEDES CCF, GIANNINI PCF, SAWAKUCHI A0, DEWITT R, NASCIMENTO JR DR, AGUIAR VAP \& ROSSI MG. 2011. Determination of controls on Holocene barrier progradation through application of OSL dating: The Ilha Comprida Barrier example, Southeastern Brazil. Marine Geology, 285: 1-16.

HOUSER C, HAPKE C \& HAMILTON S. 2008. Controls on coastal dune morphology, shoreline erosion and barrier island response to extreme storms. Geomorphology, 100: 223-240.

IRELAND S. 1987. The Holocene sedimentary history of the coastal lagoons of Rio de Janeiro State, Brazil. In: TOLLEY MJ \& SHENNAN I (Eds.). Sea-Level Changes. Oxford. Blackwell Ltd. 25-66.

LAMEGO AR. 1940. Restingas na Costa do Brasil. Divisão de Geologia e Mineralogia. DNPM, Brazil, Boletim 96: 63 pp.

LAMEGO AR. 1945. Ciclo Evolutivo das Lagunas Fluminenses. Divisão de Geologia e Mineralogia. DNPM, Brazil, Boletim 118: 47 pp.

LINS-DE-BARROS FM. 2005. Risco, Vulnerabilidade Física à Erosão Costeira e Impactos Sócio-econômicos na Orla Urbanizada do Município de Maricá, Rio de Janeiro. Revista Brasileira de Geomorfologia, 6: 83-90.

MAIA MCAC, MARTIN L \& FLEXOR JM. 1984. Evolução Holocênica da planície costeira de Jacarepaguá (RJ). In: Congresso Brasileiro de Geologia, 33., Rio de Janeiro, Brazil, 105-118.

MARTIN L, DOMINGUEZ JML \& BITTENCOURT ACSP. 2003. Fluctuating Holocene Sea Levels in Eastern and Southeastern Brazil: Evidence from Multiple Fossil and Geometric Indicators. Journal of Coastal Research, West Palm Beach, Florida, 19(1): 101-124.

MARTIN L, SUGUIO K \& FLEXOR JM. 1987. Flutuações do nível relativo do mar no Quaternário e seu papel na sedimentação costeira: exemplos brasileiros. In: Simpósio sobre Ecossistemas da Costa Sul e Sudeste Brasileira, 1., Cananeia, São Paulo, Brazil, 40-61.

MATIAS A, FERREIRA 0, VILA-CONCEJO A, GARCIA T \& DIAS JA. 2008. Classification of washover dynamics in barrier islands. Geomorphology, 97: 655-674.

McCUBBIN DG. 1982. Barrier-island and strand plain facies. In: SCHOLLE PA \& SPEARING D (Eds.). Sandstone Depositional Environments. Tulsa, Oklahoma, The American Association of Petroleum Geologists, 247-279.

MORTON RA. 2002. Factors controlling storm impacts on coastal barriers and beaches - A preliminar basis for near real-time forecasting. Journal of Coastal Research, 18(3): 486-501. 
MORTON RA \& SALLENGER AHJR. 2003. Morphological impacts of Extreme Storms on Sandy Beaches and Barriers. Journal of Coastal Research. West Palm Beach, Florida, 19(3): 560-573.

MUEHE DCEH. 1979. Sedimentology and Topography of a High Energy Coastal Environment between Rio de Janeiro and Cabo Frio - Brazil. Anais da Academia Brasileira de Ciências, 51(3): 473-481.

MUEHE DCEH. 1984. Evidências de recuo dos cordões litorâneos em direção ao continente no litoral do Rio de Janeiro. In: LACERDA LD, ARAÚJO DSD, CERQUEIRA R \& TURCQ B (Eds.). Restingas: origem, estruturas e processos. CEUFF, Niterói, Rio de Janeiro, Brazil, 75-80.

NEAL A. 2004. Ground-penetrating radar and its use in sedimentology: principles, problems and progress. Earth Science Reviews, 66: 261-330.

NEAL A \& ROBERTS CL. 2000. Applications of ground-penetrating radar (GPR) to sedimentological, geomorphological and geoarchaeological studies in coastal environments. In: PYE K \& ALLEN JRL (Eds.). Coastal and Estuarine Environments: Sedimentology, Geomorphology and Geoarchaeology. Geol. Soc. London Spec. Publ., 175: 139-171.

NEAL A, PONTEE NI, PYE K \& RICHARDS J. 2002. Internal structure of mixed-sand-and-gravel beach deposits revelead using groundpenetrating radar. Sedimentology, 49: 789-804.

PARDAL MTC. 2009. Mudanças morfológicas e suas implicações para a estabilidade da praia na Região do Recanto de Itaipuaçu, Maricá, RJ. Master Dissertation, Programa de Pós-Graduação em Geologia e Geofísica Marinha, Universidade Federal Fluminense, Rio de Janeiro, Brazil, 148 pp.

PEREIRA AJ. 2001. Investigação da Estratigrafia da Região Costeira de Maricá - Praia de Itaipuaçú (RJ) - Através do Ground Penetrating Radar (GPR). Master Dissertation, Programa de Pós-Graduação em Geologia e Geofísica Marinha, Universidade Federal Fluminense, Rio de Janeiro, Brazil, 93 pp.

PEREIRA AJ. 2009. Caracterização estratigráfica da planície costeira de Itaipuaçú (Maricá) - Rio de Janeiro, durante o Quaternário. Doctoral Thesis, Programa de Pós-Graduação em Geologia e Geofísica Marinha, Universidade Federal Fluminense, Rio de Janeiro, Brazil, 388 pp.

PEREIRA AJ, GAMBOA LAP, SILVA MAM, RODRIGUES AR \& COSTA A. 2003. A Utilização do Ground Penetrating Radar (GPR) em Estudos de Estratigrafia na Praia de Itaipuaçú - Maricá (RJ). Brazilian Journal of Geophysics. EDUFF, Niterói, Rio de Janeiro, Brazil, 21(2): 163-172.

PERRIN P. 1984. Evolução da Costa Fluminense entre as Pontas de Itacoatiara e Negra, preenchimentos e restingas. In: LACERDA LD, ARAÚJO DSD, CERQUEIRA R \& TURCQ B (Eds.). Restingas, origens, processos. CEUFF, Niterói, Rio de Janeiro, Brazil, 65-74.

PETTIJOHN FJ. 1975. Sedimentary Rocks. 3rd ed., Harper and Row Publishers, New York. 628 pp.
PHANTUWONGRAJ S, CHOOWONG M, NANAYAMA F, HISADA K, CHARUSIRI P, CHUTAKOSITKANON V, PAILOPLEE $S$ \& CHABANGBON A. 2013. Coastal geomorphic conditions and styles of storm surge washover deposits from Southern Thailand. Geomorphology, 192: 43-58

RONCARATI H \& NEVES LE. 1976. Projeto Jacarepaguá: Estudo geológico preliminar dos sedimentos recentes superficiais da Baixada de Jacarepaguá, Município do Rio de Janeiro - RJ, Brazil. PETROBRAS, CENPES. DEXPRO. $89 \mathrm{pp}$.

SCHWARTZ ML. 1971. The multiple causality of barrier island. Journal of Geology, 79: 91-94.

SEDRATI M, CIAVOLA P \& ARMAROLI C. 2011. Morphodynamic evoIution of a microtidal barrier, the role of overwash: Bevano, Northern Adriatic Sea. Journal of Coastal Research, SI 64 (Proceedings of the 11th International Coastal Symposium), 696-700.

SILVA MAM. 1972. Relatório Final de Iniciação Científica, Conselho Nacional de Desenvolvimento Científico e Tecnológico (CNPq). 20 pp.

SILVA ALC. 2006. Comportamento Morfológico e Sedimentológico do Litoral de Itaipuaçú (Maricá) e Piratininga (Niterói), RJ, nas últimas três décadas. Master Dissertation, Programa de Pós-Graduação em Geologia e Geofísica Marinha, Universidade Federal Fluminense. Rio de Janeiro, Brazil, 153 pp.

SILVA ALC. 2011. Arquitetura sedimentar e evolução geológica da planície costeira central de Maricá (RJ) ao longo do Quaternário. Doctoral Thesis, Programa de Pós-Graduação em Geologia e Geofísica Marinha, Universidade Federal Fluminense, Rio de Janeiro, Brazil. $185 \mathrm{pp}$.

SILVA ALC \& SILVA MAM. 2010. Caracterização geomorfológica e sedimentar da planície costeira central de Maricá (Rio de Janeiro). VII Simpósio Nacional de Geomorfologia. Recife, Brazil, 1-15.

SILVA ALC, SILVA MAM \& SANTOS CL. 2008a. Comportamento Morfológico e Sedimentar da Praia de Itaipuaçú (Maricá, RJ) nas últimas Três Décadas. Revista Brasileira de Geociências, 38(1): 87-97.

SILVA ALC, SILVA MAM, SANTOS CL, RIBEIRO GB, SANTOS RA \& VASCONCELOS SC. 2008b. Retrogradação da Barreira Arenosa e Formação de Leques de Arrombamento na Praia de Itaipuaçú (Oeste de Maricá, RJ). Revista Brasileira de Geomorfologia, 9(2): 75-82.

SILVA ALC, SILVA MAM, SOUZA RS \& PINTO MLV. 2014a. The role of beachrocks on the evolution of the Holocene barrier systems in Rio de Janeiro, southeastern Brazil. In: GREEN AN \& COOPER JAG (Eds.). Proceedings 13th International Coastal Symposium (Durban, South Africa), Journal of Coastal Research, SI 70: 170-175.

SILVA ALC, SILVA MAM, GAMBOA LAP \& RODRIGUES AR. 2014b. Sedimentary architecture and depositional evolution of the Quaternary 
coastal plain of Maricá, Rio de Janeiro, Brazil. Brazilian Journal of Geology, 44(2): 191-206.

SILVA ALC, SILVA MAM, GRALATO JCA \& SILVESTRE CP. 2014C. Caracterização geomorfológica e sedimentar da planície costeira de Maricá (Rio de Janeiro). Revista Brasileira de Geomorfologia, 15(2): 231-249.

SWITZER AD, BRISTOW CS \& JONES BG. 2006. Investigation of Largescale Washover of a Small Barrier System on the Southeast Australian Coast using Ground Penetrating Radar. Sedimentary Geology, 183: 145-156.

TOMAZELLI LJ \& DILLENBURG SR. 2007. Sedimentary facies and stratigraphy of a last interglacial coastal barrier in south Brazil. Marine
Geology, 244: 33-45.

TOMAZELLI LJ, DILLENBURG SR \& VILLWOCK JA. 2000. Late Quaternary geological history of Rio Grande do Sul Coastal Plain, Southern Brazil. Revista Brasileira de Geociências, 30(3): 474-476.

TURCQ B, MARTIN L, FLEXOR JM, SUGUIO K, PIERRE C \& TASAYACOORTEGA L. 1999. Origin and Evolution of the Quaternary Coastal Plain between Guaratiba and Cabo Frio, State of Rio de Janeiro, Brazil. Environmental Geochemistry of Coastal Lagoon Systems. Rio de Janeiro, Brazil - Série Geoquímica Ambiental, 6: 25-46.

WANG P \& HORWITZ MH. 2007. Erosional and Depositional Characteristics of Regional Overwash Deposits caused by Multiple Hurricanes. Sedimentology, 54: 545-564.

Recebido em 5 setembro, 2014 / Aceito em 23 fevereiro, 2016

Received on September 5, 2014 / Accepted on February 23, 2016

\section{NOTES ABOUT THE AUTHORS}

Carolina Pereira Silvestre. Geographer from the Universidade do Estado do Rio de Janeiro (UERJ) in 2010. Master in Marine Geology and Geophysics from the Universidade Federal Fluminense (UFF). Currently, is a doctoral student at the Geology and Geophysics Department (Oceans and Earth Dynamics) at UFF.

André Luiz Carvalho da Silva. Geographer from the UERJ in 2003. Master and Doctor in Marine Geology and Geophysics from UFF in 2006 and 2011, respectively. Associate professor in the Department of Geography at UERJ since 2012.

Maria Augusta Martins da Silva. Geologist from the Universidade Federal do Rio de Janeiro (UFRJ) in 1973. Master in Geosciences from Universidade Federal do Rio Grande do Sul (UFRGS) in 1976 and from Columbia University (USA) in 1980. Ph.D. in Geosciences from Columbia University (USA) in 1983. Professor in the Department of Geology at UFF since 1985 (retired now).

Amilsom Rangel Rodrigues. Oceanographer from UERJ in 1986. Master in Geophysics from Universidade Federal do Pará (UFPA) in 1992. Currently, is a doctoral student at the Geology and Geophysics Department (Oceans and Earth Dynamics) at UFF. 